\title{
Expression of nuclear progesterone receptor and progesterone receptor membrane components 1 and 2 in the oviduct of cyclic and pregnant cows during the post-ovulation period
}

Marie Saint-Dizier ${ }^{1,2,3^{*}}$, Olivier Sandra ${ }^{1,2}$, Stéphane Ployart ${ }^{1,2}$, Martine Chebrout ${ }^{1,2}$ and Fabienne Constant ${ }^{1,2}$

\begin{abstract}
Background: Progesterone (P4) may modulate oviductal functions to promote early embryo development in cattle. In addition to its nuclear receptor (PR), P4 may mediate its actions through P4 receptor membrane component 1 (PGRMC1) and its relative, PGRMC2. Two successive experiments were undertaken to characterise the expression of PR, PGRMC1 and PGRMC2 in the bovine oviduct during the post-ovulation period, and to relate their expression to the presence of an embryo, the proximity of the $\mathrm{CL}$ and to the region of the oviduct.

Methods: In the first experiment (Exp. I), whole oviduct sections were collected from Holstein cows at Day 1.5, Day 4 and Day 5 post-ovulation ( $n=2$ cows per stage). The expression of PR, PGRMC1 and PGRMC2 was studied in the ampulla and isthmus by RT-PCR, western-blot and immunohistochemistry. In Exp. II, oviduct epithelial cells were collected from cyclic and pregnant Charolais cows ( $n=4$ cows per status) at Day 3.5 post-ovulation and mRNA expression of $P R, P G R M C 1$ and $P G R M C 2$ was examined in the ampulla and isthmus by real-time quantitative PCR.

Results: In Exp. I, PR, PGRMC1 and PGRMC2 were expressed in all oviduct samples. PGRMC1 was mainly localised in the luminal epithelium whereas PR and PGRMC2 were localised in the epithelium as well as in the muscle and stroma layers of the oviduct. The expression was primarily nuclear for PR, primarily cytoplasmic for PGRMC1 and both nuclear and cytoplasmic for PGRMC2. In Exp. II, mRNA levels for PR, PGRMC1 and PGRMC2 were not affected by either the pregnancy status or the side relative to the $C L$. However, the expression of $P R$ and $P G R M C 2$ varied significantly with the region of the oviduct: $P R$ was more highly expressed in the isthmus whereas $P G R M C 2$ was more highly expressed in the ampulla.

Conclusions: This is the first evidence of PGRMC2 expression in the bovine oviduct. Our findings suggest that P4 regulates the functions of the bovine oviduct in a region-specific manner and through both classical and non classical pathways during the post-ovulation period.
\end{abstract}

Keywords: PR, PGRMC1, PGRMC2, Oviduct, Bovine, Expression

\footnotetext{
*Correspondence: stdizier@agroparistech.fr

'INRA, UMR 1198 Biologie du Développement et Reproduction, F-78352,

Jouy-en-Josas, France

2Université Paris-Est, Ecole Nationale Vétérinaire d'Alfort, UMR 1198, 7 av. du

Général-de-Gaulle, F-94704, Maisons-Alfort, France

Full list of author information is available at the end of the article
} 


\section{Background}

Progesterone (P4) plays a key role in the establishment and maintenance of pregnancy in cattle [1]. Several studies have demonstrated a positive association between milk or plasma P4 concentration in the immediate post-insemination period and bovine embryo survival and/or development [2-6]. This positive effect of P4 on embryo survival in inseminated cows was bypassed by transfer into the uterus of lactating Holstein cows of fresh morulas or blastocysts [2], suggesting that P4 may improve early embryo development via changes in the oviductal environment during the first days of pregnancy. Indeed, bovine embryos develop to the morula stage within the oviduct in the first 5 days of pregnancy, before entering the uterus [1]. The proximal part of the oviduct, referred to as the ampulla, is particularly implicated in the transport of the oocyte-cumulus complex and fertilisation, whereas the distal part, named the isthmus, is responsible for sperm storage and embryo transport toward the uterus [7-9]. The oviduct epithelium provides nutrients (e.g. energetic substrates, ions, amino acids) and local growth factors [10,11], that can be modified quantitatively [12] and qualitatively [13] by circulating P4 secreted by the corpus luteum (CL). Moreover, P4 could influence embryo development through the regulation of its transport to the uterus [14]. In cattle, P4 has been shown to reduce oviduct motility in vivo [15] and to reduce ciliary motility in tubal explants ex vivo through rapid non genomic actions [16]. However, the mechanisms by which P4 modulates the tubal micro-environment in cattle are still poorly understood.

P4 may act in the oviduct through at least two types of receptors: the conventional nuclear receptor PR, that exists in two isoforms PRA and PRB (arising from a single gene) which are both expressed in the bovine oviduct $[17,18]$, and two potential P4 receptors, referred to as progesterone receptor membrane component (PGRMC) 1 and the closely related PGRMC2, encoded by two different genes [19]. While minimal information is available concerning PGRMC2, PGRMC1 is a vertebrate 26-28 $\mathrm{kDa}$ protein that contains a single membrane-spanning domain and belongs to the membrane-associated $\mathrm{P} 4$ receptor (MAPR) family [20]. Recent studies suggest that PGRMC1 mediates several P4 actions in reproductive organs, such as anti-apoptotic action in rat granulosa cells [21], sperm acrosome reaction in porcine and human [22], oocyte maturation in bovine [23,24] and myometrium relaxation during pregnancy in human [25]. Furthermore, PGRMC1 has recently been immunolocalised in the bovine genital tract, including the oviduct, during the oestrous cycle [26].

In order to explore the expression of nuclear and membrane $\mathrm{P} 4$ receptors in the bovine oviduct during the post-ovulation period, two experiments were carried out. The first experiment (Exp. I) was undertaken to detect mRNA and localise protein expression of PR, PGRMC1 and PGRMC2 in the bovine oviduct during the first 5 days post-ovulation. The second experiment (Exp. II) was designed to compare the expression of these three receptors in oviduct epithelial cells at Day 3.5 postovulation in relation to the pregnancy status, to the side relative to the $\mathrm{CL}$ and to the region of the oviduct.

\section{Methods}

\section{Treatment of animals and oviduct collection}

All procedures described within were approved by the Regional Ethical Committee of Paris-Sud and performed in accordance with the International Guiding Principles for Biomedical Research Involving Animals.

In Exp. I, six non lactating Holstein cows (age: 7.0 \pm 1.4 years) were synchronised using a subcutaneous implant of P4 (Crestar $\mathrm{SO}^{\circledR}$, Intervet-Schering-Plough, Angers, France) left for 10 days, with $500 \mu \mathrm{g}$ of cloprostenol (Estrumate ${ }^{\circledR}$, Intervet-Schering-Plough) IM-injected 2 days before implant removal and 400 IU equine Chorionic Gonadotropin (CHRONO-GEST ${ }^{\circledR}$ PMSG, Intervet-Schering-Plough) IMinjected on the day of implant removal. Day 0 was considered as the day of presumed ovulation, i.e. $48 \mathrm{~h}$ after implant removal. Cows were killed either at Day 1.5, Day 4 or Day 5 post-ovulation ( $\mathrm{n}=2$ for each stage) in a local INRA slaughterhouse for tissue collection.

In Exp. II, 20 multiparous non lactating Charolais cows (age: $7.1 \pm 0.3$ years) were synchronised for oestrus using a subcutaneous implant of $\mathrm{P} 4$ (Crestar $\mathrm{SO}^{\circledR}$ ) inserted for 11 days, with $10.5 \mu \mathrm{g}$ busereline acetate (Receptal $^{\circledR}$, Intervet-Schering-Plough) IM-injected on the day of implant insertion, $15 \mathrm{mg}$ luprostiol (Prosol$\operatorname{vin}^{\circledR}$, Virbac, Carros, France) IM-injected 2 days before implant removal and 400 IU equine Chorionic Gonadotropin (CHRONO-GEST ${ }^{\circledR}$ PMSG) IM-injected on the day of implant removal. Day 0 was considered as the day of presumed ovulation, i.e. $48 \mathrm{~h}$ after implant removal. In order to get pregnant oviducts, 12 cows out of 20 were artificially inseminated twice at Day 0 and Day 0.5. All cows were killed at Day 3.5 post-ovulation for tissue collection in a local INRA slaughterhouse. In Exp. I and II, ovaries and genital tract were recovered from cows within $20 \mathrm{~min}$ of death. Cows that did not ovulate or that did ovulate twice (two corpora lutea) were discarded. Furthermore, the appearance of the CL varied with the post-ovulation stage: a small corpus hemorrhagicum was observed at Day 1.5 post-ovulation, a very early corpus luteum, occasionally filled with blood, was observed at Days 3.5-4 post-ovulation, and a large corpus luteum was observed at Day 5 post-ovulation, as previously described [27]. Oviducts ipsilateral and contralateral to the $\mathrm{CL}$ were separated from the uterus 
at the utero-tubal junction, trimmed free of surrounding tissue then flushed with $2 \mathrm{ml}$ of Phosphate Buffer Saline (PBS, Sigma, Saint-Quentin Fallavier, France). In Exp. II, the flushing from the oviduct ipsilateral to the $\mathrm{CL}$ was examined under the microscope for the presence of an oocyte or an embryo. Non inseminated and inseminated cows in which no oocyte and no embryo, respectively, could be recovered, were excluded. Eventually, four cyclic cows (for which one oocyte was found in the oviductal flushing) and four pregnant cows (for which one embryo at the 8- to 16-cell stage was found in the oviductal flushing) were analyzed in Exp. II.

\section{Preparation of oviduct samples}

In Exp. I, ampulla and isthmus were separated then cut into $1-\mathrm{cm}$ long sections and whole tissues were either snap frozen in liquid nitrogen or embedded in OCT (Embedding Matrix, Cellpath, Newton, UK), then frozen in liquid nitrogen vapours and stored at $-80^{\circ} \mathrm{C}$ pending analysis.

In Exp. II, the ampulla and isthmus were opened longitudinally and oviduct epithelial cells were recovered by scraping the mucosal layer with a sterile scalpel. Cells from both regions were immediately transferred into a sterile cryotube and snap frozen in liquid nitrogen then stored at $-80^{\circ} \mathrm{C}$ pending analysis.

\section{Preparation of cDNAs}

In Exp. I, total RNA was extracted from whole oviduct sections in TRIzol reagent (Invitrogen, Cergy-Pontoise, France) using a homogeniser (Polytron ${ }^{\circledR}$ PT-MR 2100, Kinematica AG, Littau, Switzerland), then treated with recombinant DNase I (Roche Applied Science, Mannheim, Germany) as described in the manufacturer's instructions, and stored at $-80^{\circ} \mathrm{C}$ until use in reverse transcription (RT).

In Exp. II, total RNA was extracted from oviduct cells using the RNeasy Mini kit (Qiagen, Courtaboeuf, France) then treated with RNase Inhibitor (40 U/ $\mu$ l; Invitrogen) and recombinant DNase I (Roche Applied Science). RNA samples were then migrated on an ethidium bromide-treated 1\% agarose gel to assess their integrity (by observation of $18 \mathrm{~S}$ and $28 \mathrm{~S}$ rRNA intensities after UV light exposure). Six RNA samples (out of 32) were suboptimal and discarded.

In both studies, RNA samples were quantified by spectrophotometry and $1 \mu \mathrm{g}$ was reverse transcribed using oligo(dT) primers (Invitrogen) and the Superscript II reverse transcriptase (Invitrogen) in a $20-\mu$ l reaction mixture according to manufacturer's instructions. The reverse-transcribed cDNA was diluted 5 times $(100 \mu \mathrm{l}$ final volume) and stored at $-20^{\circ} \mathrm{C}$ until used as template in conventional or real-time quantitative PCR mixture.

\section{Amplification of CDNA by conventional and quantitative real-time PCR (qPCR)}

Same primer sets were used in both conventional and qPCR. Primer sets were developed using known bovine sequences and designed using the Primer 3 web interface [28] for target genes and using Primer Express software (v3.0, Applied Biosystems, Life Technologies, Carlsbad, CA, USA) for two reference genes, GAPDH and SLC30A6 (see Table 1 for details). Primers for $P R$ were designed to detect both PRA and PRB isoforms. The specificity of each conventional and quantitative PCR products was verified in the Basic Local Alignment Search Tool [29] and by DNA sequencing (Beckman Coulter Genomics, Takeley, UK). Conventional PCR

Table 1 Primer sets used in conventional and real-time PCR

\begin{tabular}{|c|c|c|c|}
\hline Gene name (abbreviation) & GenBank accession no. & Primer sequence $\left(5^{\prime} \rightarrow 3^{\prime}\right)$ & Product length (bp) \\
\hline \multirow[t]{2}{*}{ Progesterone receptor (PR) } & \multirow[t]{2}{*}{ AY656812 } & Forward: GATGCTATATTTGGGCCTGA & \multirow[t]{2}{*}{266} \\
\hline & & Reverse: CTCCTTITTGCCTCAAACCA & \\
\hline \multirow[t]{2}{*}{ Progesterone receptor membrane component 1 (PGRMC1) } & \multirow[t]{2}{*}{ BC1184441 } & Forward: GCAAGCTTTGGCGAAAATCA & \multirow[t]{2}{*}{121} \\
\hline & & Reverse: CCCCTCGCATGTCCAATCAT & \\
\hline \multirow[t]{2}{*}{ Progesterone receptor membrane component 2 (PGRMC2) } & \multirow[t]{2}{*}{ NM_001099060 } & Forward: AGGGGAAGAACCGTCAGAAT & \multirow[t]{2}{*}{280} \\
\hline & & Reverse: AAGCCCCACCAGACATTACA & \\
\hline \multirow[t]{2}{*}{ Glyceraldehyde 3-phosphate dehydrogenase (GAPDH) } & \multirow[t]{2}{*}{ NM_001034034 } & Forward: GCTGAGGCTCCCATGTTTGT & \multirow[t]{2}{*}{151} \\
\hline & & Reverse: TCATAAGTCCCTCCACGATGC & \\
\hline \multirow{2}{*}{$\begin{array}{l}\text { Solute carrier family } 30 \text { (zinc transporter), } \\
\text { member } 6 \text { (SLC30A6) }\end{array}$} & \multirow[t]{2}{*}{ NM_001075766 } & Forward: TGATGAGGAAACCTAGCCCTGCC & \multirow[t]{2}{*}{143} \\
\hline & & Reverse: TCGGGCTGCTCCAAAAAGCGT & \\
\hline \multirow[t]{2}{*}{ Beta actin (ACTB) } & \multirow[t]{2}{*}{ NM_173979 } & Forward: CTGGACTTCGAGCAGGAGAT & \multirow[t]{2}{*}{140} \\
\hline & & Reverse: AGGAAGGAAGGCTGGAAGAG & \\
\hline
\end{tabular}


reactions were performed in Exp. I using a Mastercycler (Eppendorf, Hamburg, Germany). Reactions were performed in a $25-\mu \mathrm{l}$ mixture containing $0.5 \mathrm{IU}$ of Taq polymerase and $5 \times$ buffer (QBiogene, Illkirch, France), $0.5 \mu \mathrm{M}$ of each primer, $10 \mathrm{mM} \mathrm{dNTPs}$, and $1 \mu \mathrm{l}$ of diluted cDNA. A negative control using water instead of cDNA was added to each PCR reaction. The amplification of ACTB cDNA was used as internal control (primer sequences in Table 1). Reaction times were: $1 \mathrm{~min}$ at $94^{\circ} \mathrm{C}$ then 35 cycles of $30 \mathrm{sec}$ at $94^{\circ} \mathrm{C}, 30 \mathrm{sec}$ at $60^{\circ} \mathrm{C}$ and $30 \mathrm{sec}$ at $72^{\circ} \mathrm{C}$, then $15 \mathrm{~min}$ at $72^{\circ} \mathrm{C}$. The amplified products were resolved by electrophoresis on an ethidium bromide-treated $2 \%$ agarose gel. The quantification of mRNAs was examined in Exp. II by qPCR on a LightCycler $^{\circledR} 480$ apparatus (Roche, Mannheim, Germany). For each gene, a 10-fold dilution series of the purified PCR product (Wizard PCR Preps DNA Purification System, Promega, Madison WI, USA) was amplified simultaneously with the samples to establish a standard curve. Reactions were performed in a $20-\mu$ l reaction mixture containing either $5 \mu \mathrm{l}$ of diluted cDNA or diluted standard, $10 \mu \mathrm{l}$ of LightCycler 480 SYBR Green I Master mix (Roche), $0.3 \mu \mathrm{M}$ of forward and reverse primers and PCR-grade water up to the final volume. As negative control, water instead of cDNA was used. Cycling conditions were: denaturation at $95^{\circ} \mathrm{C}$ for $10 \mathrm{~min}$ followed by 45 cycles of amplification $\left(95^{\circ} \mathrm{C}\right.$ for $10 \mathrm{sec}$, $60^{\circ} \mathrm{C}$ for $10 \mathrm{sec}$ and $72^{\circ} \mathrm{C}$ for $10 \mathrm{sec}$ ) with a single acquisition of fluorescence at the end of the extension step. After amplification, the samples were heated at $0.1^{\circ} \mathrm{C} / \mathrm{sec}$ from 60 to $97^{\circ} \mathrm{C}$ with continuous reading of fluorescence to obtain a melting curve. The specificity of qPCR product was verified using the melting curve analysis program of the Lightcycler software (LightCycler ${ }^{\circledR} 480$ Software release, version 1.5.0.33, Roche). All qPCR products displayed a single peak in the melting curve analysis (data not shown). The concentration of each gene was calculated in duplicate by reference to the respective standard curve using the maximum second-derivative analysis of the Lightcycler software (Roche). Finally, the relative level of gene expression was expressed as the ratio of target gene mean value to the geometric mean value of the two reference genes, GAPDH and SLC30A6.

\section{Western blot analysis}

In order to test the specificity of antibodies raised against P4 receptors, three oviduct sections from Exp. I were used for protein extraction and western-blot analysis. Tissues were homogenized in lysis buffer (Ripa buffer, Pierce, Rockford, USA) containing proteinase and phosphatase inhibitors for protein extraction. Protein samples $(60 \mu \mathrm{g})$ were separated on a SDS-PAGE gel (Biorad, Marnes-la-Coquette, France) containing 10\% acrylamide and $5 \% \beta$-mercaptoethanol then transferred onto a $0.2-\mu \mathrm{m}$ nitrocellulose membrane (Schleicher \& Schuell, Dassel, Germany) overnight at $4^{\circ} \mathrm{C}$. Membranes were blocked with $5 \%$ dried milk in Tris Buffer Saline (TBS: Tris- $\mathrm{HCl}$ buffer $10 \mathrm{mM} \mathrm{pH} \mathrm{8,} \mathrm{NaCl} 150 \mathrm{mM}$ ) for $1 \mathrm{~h}$ then incubated with one of the following primary antibodies: 1) a monoclonal mouse anti-PR antibody (MA1-410 raised against a peptide corresponding to amino acids 553-547 of the human PR; Affinity BioReagents, Golden, USA) and diluted at 1:200;2) a polyclonal rabbit anti-PGRMC1 antibody (raised against a peptide corresponding to amino acids $1-14$ of the native porcine PGRMC1 [30]; gift from Prof. M. Wehling, University Medicine Mannheim, University of Heidelberg, Germany) diluted at 1:500; 3) a monoclonal mouse antiPGRMC2 antibody (clone 3C11 raised against a peptide corresponding to amino acids 124-224 of the human PGRMC2; Sigma-Aldrich, Saint Louis, USA) diluted at 1:200. Loading controls were carried out using either an anti- $\alpha$-tubulin (mouse monoclonal antibody, clone DM1A, Sigma) or an anti- $\beta$-actin (mouse monoclonal antibody, clone AC-74, Sigma) antibody. Membranes were incubated in $2 \%$ dried milk in TBS containing $0.05 \%$ of Tween-20 (TBS-Tween) overnight at $4^{\circ} \mathrm{C}$. After washing in TBS-Tween, the membranes were incubated with either an anti-mouse (for PR and PGRMC2) or an anti-rabbit (for PGRMC1) horseradish peroxidaseconjugated IgG secondary antibody (Sigma) at dilutions of 1:5000 and 1:30.000, respectively, in $2 \%$ dried milk in TBS-Tween for $1 \mathrm{~h}$ at room temperature. After washing in TBS-Tween, the membrane was incubated with enhanced chemiluminescence reagent detection solution (Super Signal West Pico, Pierce) for $5 \mathrm{~min}$ in the dark. Finally, a film (Hyperfilm ECL, Amersham Biosciences, Orsay, France) was exposed to the membrane to visualize protein expression.

\section{Immunohistochemistry}

Frozen oviduct samples from Exp. I were serially sectioned $(7 \mu \mathrm{m})$ with a cryostat. Sections were mounted on Superfrost Plus slides (Menzel-Gläser, Braunshweig, Germany), fixed for $5 \mathrm{~min}$ in acetone at $-20^{\circ} \mathrm{C}$ then stored at $-80^{\circ} \mathrm{C}$ until use. Non-specific protein binding was inhibited by incubation with normal porcine serum (1:10 dilution in PBS; Interchim, Montluçon, France) for $30 \mathrm{~min}$ at room temperature. Sections were incubated with either the anti-PR antibody (1:1000 dilution in PBS), the anti-PGRMC1 antibody (1:1000 dilution in PBS) or the anti-PGRMC2 antibody (1:200 in PBS). Sections were incubated overnight at $4^{\circ} \mathrm{C}$ in a moist chamber. After washing in PBS, sections were incubated with either anti-mouse (for PR and PGRMC2) or anti-rabbit (for PGRMC1) biotinylated secondary antibodies (LSAB kit, Dako, Trappes, France) at room temperature for 30 min. Sections were then treated with $3 \% \mathrm{H}_{2} \mathrm{O}_{2}$ for $5 \mathrm{~min}$ 
and incubated with a streptavidin-horseradish peroxidase complex (LSAB kit) at room temperature for $15 \mathrm{~min}$. The signal was detected using a solution of 3-amino-9ethylcarbazole (AEC; LSAB kit) for $10 \mathrm{~min}$. Sections were counterstained with hematoxylin and mounted in Immu-Mount mounting solution (Thermon Electron, Courtaboeuf, France) for light microscopy. For control sections, the primary antibody was replaced at the same dilution by mouse IgG for PR, rabbit serum for PGRMC1 or mouse $\mathrm{IgG}_{1}$ for PGRMC2.

\section{Statistical analysis}

Data are presented as means \pm SEM. For statistical analysis of qRT-PCR data, the GLM procedure of SAS software (SAS Institute Inc., Cary, NC, USA) was used. A three-way ANOVA was used to study the effect of the cow status (cyclic versus pregnant), the oviduct side relative to that of the CL (ipsilateral versus contralateral) and the oviduct section (ampulla versus isthmus) on mRNA levels, followed, when necessary, by a multiple $t$-test analysis. To account for potential correlations between observations made on the same cow, the factors "oviduct side" and "oviduct section" were considered as repeated measures. A p value $<0.05$ was considered significant.

\section{Results}

Experiment I: expression and localisation of PR, PGRMC1 and PGRMC2 in whole oviduct sections between Day 1.5 and Day 5 post-ovulation

Conventional RT-PCR evidenced the expression of $P R$, PGRMC1 and PGRMC2 mRNAs in both ipsilateral and contralateral ampulla and isthmus at Day 1.5, Day 4 and
Day 5 post-ovulation (Figure 1) whereas negative controls using water instead of cDNA showed no signal (data not shown).

The specificity of antibodies raised against target proteins was examined by western blot analysis. The antiPR antibody detected both PR-A (95 kDa) and PR-B $(120 \mathrm{kDa})$ isoforms in the ampulla and isthmus at each stage examined (see Figure 2 for one ampulla at Day 5). Western blotting analysis of the same oviduct sample detected two bands at $23 \mathrm{kDa}$ and $28 \mathrm{kDa}$ using the anti-PGRMC1 antibody, and a single band at $26 \mathrm{kDa}$ using the anti-PGRMC2 antibody (Figure 2).

Immunocytochemistry for PR revealed a specific nuclear staining in the luminal epithelium, the stromal cells and the muscle layer in both the ampulla (Figures $3 \mathrm{~A}, \mathrm{~B}$ ) and the isthmus (Figures $3 \mathrm{C}, \mathrm{D}$ ). A weak cytoplasmic staining was also present in the luminal epithelium in both oviductal sections (Figure 3A inset, C). Examination of PGRMC1 localisation revealed an intense cytoplasmic staining in the luminal epithelium in both the ampulla (Figures 4A, B) and the isthmus (Figures 4C, D), while the muscular and stromal layers were weakly stained in both parts of the oviduct. Examination of PGRMC2 localisation revealed a cytoplasmic staining in the luminal epithelium and a nuclear staining in the stromal and muscle layers in both the ampulla (Figures 5A, B) and the isthmus (Figures 5C, D). Higher magnification showed a discrete nuclear PGRMC2 staining in the epithelial compartment (Figure 5A inset). No obvious differences in localisation patterns of PR, PGRMC1 and PGRMC2 were observed between ipsi- and contralateral oviducts or according to the stage post-ovulation (Day 1.5, Day 4 or Day 5).

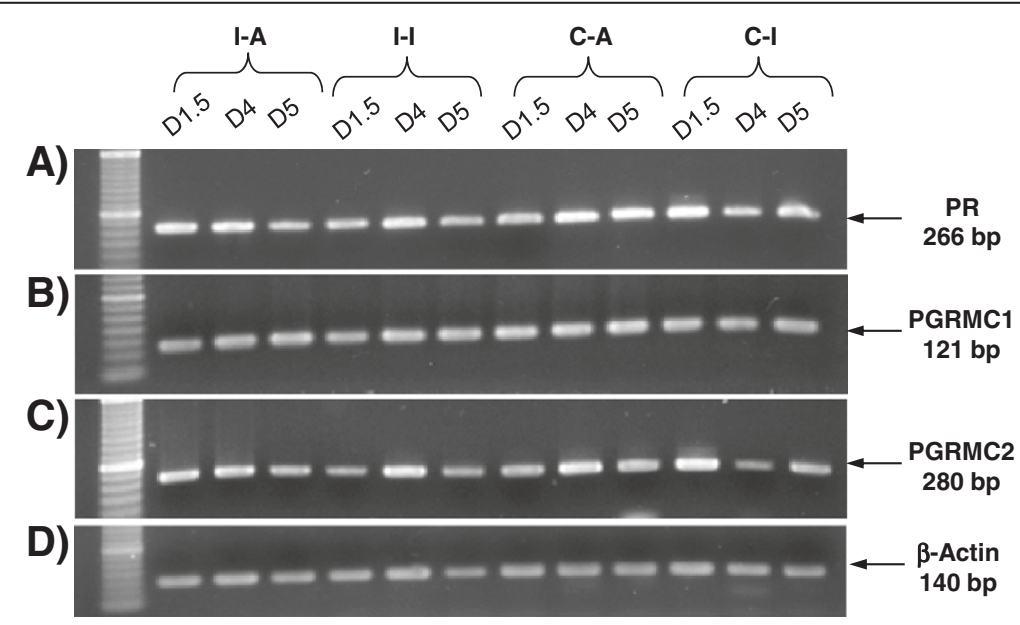

Figure 1 Expression of PR, PGRMC1 and PGRMC2 mRNAs in the bovine oviduct. Messenger RNA transcripts for PR (A), PGRMC1 (B) and PGRMC2 (C) detected by conventional RT-PCR in bovine whole oviduct sections at Day 1.5, Day 4 and Day 5 post-ovulation. Experiments were repeated twice and one representative assay is shown. Arrows indicate the size of the amplified product. I-A: ipsilateral ampulla; I-I: ipsilateral isthmus; C-A: contralateral ampulla; C-I: contralateral isthmus. 

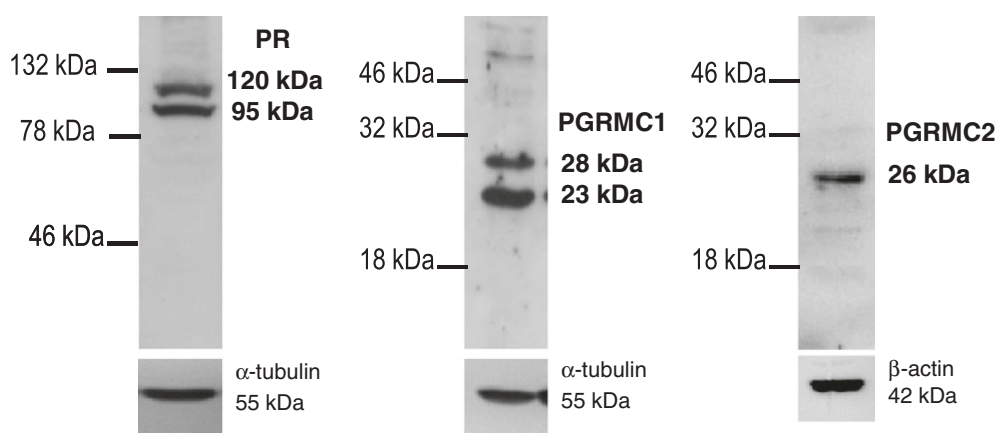

Figure 2 Western blots for PR, PGRMC1 and PGRMC2 in the bovine oviduct. Western blot analysis of PR, PGRMC1 and PGRMC2 in one bovine whole ampulla section at Day 5 post-ovulation. Molecular weight markers are indicated on the left of each blot and molecular weights of the bands are indicated on the right. Experiments were repeated three times and one representative blot is shown.

\section{Experiment II: Expression of PR, PGRMC1 and PGRMC2 mRNAs in oviduct epithelial cells at Day 3.5 post- ovulation}

To further characterise the expression of $\mathrm{P} 4$ receptors, a RT-qPCR approach was applied to oviduct epithelial cells at Day 3.5 post-ovulation in both cyclic and pregnant cows. Statistical analysis revealed no effect of either the cow status (cyclic versus pregnant) or the side relative to the CL (ipsilateral versus contralateral) on any gene expression. However, when ipsilateral and contralateral oviducts were grouped, the expression of $P R$ mRNA was significantly higher $(1.8$-fold higher, $\mathrm{p}=0.004)$ in the isthmus than in the ampulla in cyclic cows (Figure 6A). In contrast, while PGRMC1 expression did not vary according to the oviduct section (Figure 6B), the amount of PGRMC2 mRNA was significantly higher (2-fold higher, $\mathrm{p}=0.04)$ in the ampulla than in the isthmus in cyclic cows (Figure 6C). The effect of the oviduct region on $P R$ and $P G R M C 2$ gene expression remained significant when cyclic and pregnant oviducts were pooled ( $\mathrm{p}=0.03$ for both receptors).

\section{Discussion}

Our results demonstrate the expression of PR, PGRMC1 and, for the first time, of PGRMC2, in several compartments of the bovine oviduct between Day 1.5 and Day 5 post-ovulation. To our knowledge, this is the first exploration of PGRMC1 and PGRMC2 gene expression in

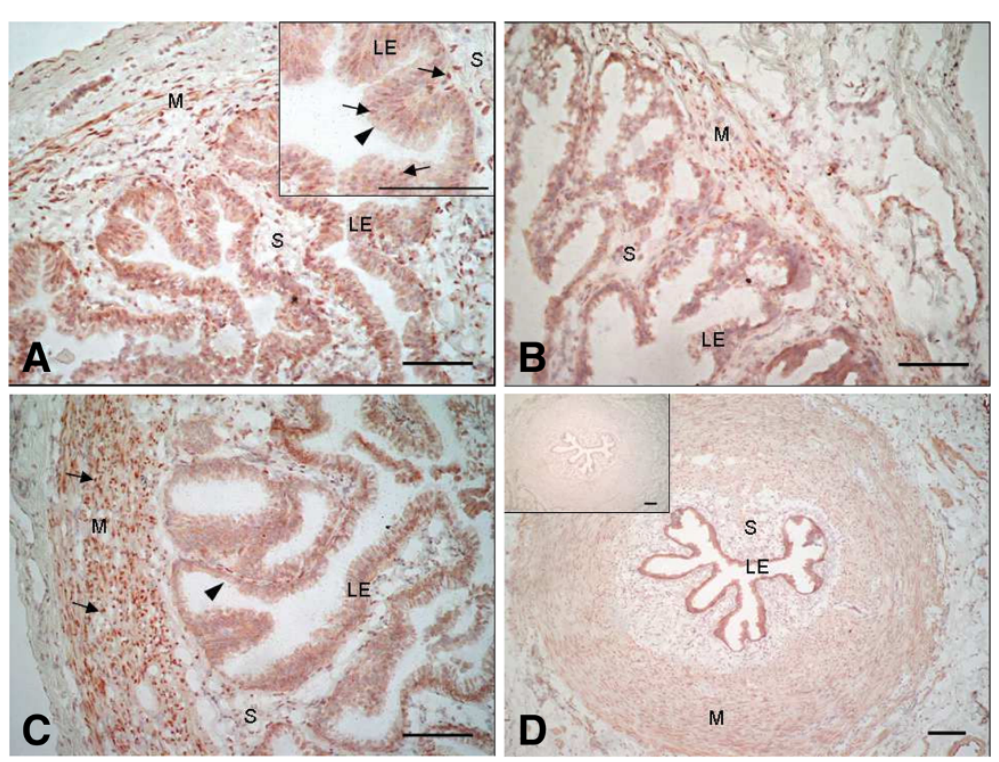

Figure 3 Localisation of PR in the bovine oviduct by immunohistochemistry. Representative images of PR immunohistochemical localisation in the ampulla (A, B) and the isthmus (C, D) of bovine oviducts at Day $1.5(\mathbf{A}, \mathbf{C})$ and Day 5 (B, D) post-Al. A inset: magnification of the luminal epithelium showing a nuclear and cytoplasmic staining in the epithelial cells and a nuclear staining in the stromal cells. D inset: control section incubated with mouse lgG in place of primary antibody. Black arrows indicate nuclear staining and arrow heads indicate cytoplasmic staining. LE: luminal epithelium; S: stroma; M: muscle. Original magnification A-C X200 and D x100. Scale bars: $100 \mu \mathrm{m}$. 

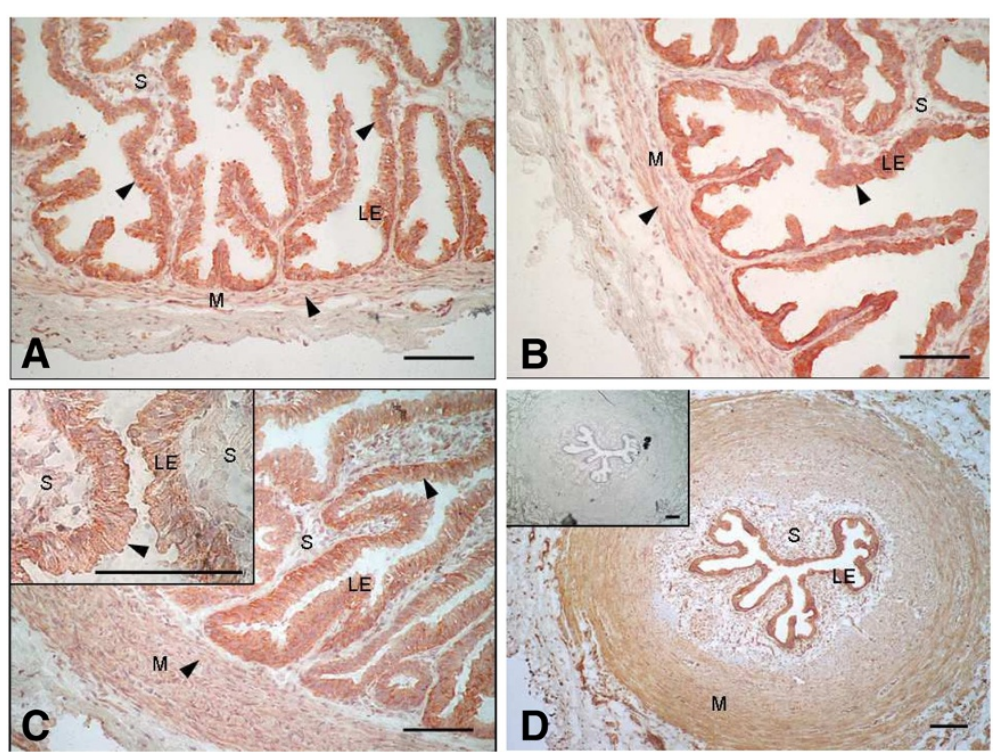

Figure 4 Localisation of PGRMC1 in the bovine oviduct by immunohistochemistry. Representative images of PGRMC1

immunohistochemical localisation in the ampulla $(\mathbf{A}, \mathbf{B})$ and the isthmus $(\mathbf{C}, \mathbf{D})$ of bovine oviducts at Day $1.5(\mathbf{A}, \mathbf{C})$ and Day $5(\mathbf{B}, \mathbf{D})$ post-Al. $C$ inset: magnification of the luminal epithelium showing a cytoplasmic staining mainly localised in the epithelial cells. $D$ inset: control section incubated with rabbit serum in place of primary antibody. Arrow heads indicate cytoplasmic staining. LE: luminal epithelium; S: stroma; M: muscle. Original magnification A-C X200, D x100 and C inset x1000. Scale bars: $100 \mu \mathrm{m}$.

this organ. At Day 3.5 post-ovulation, the $P R$ gene was more highly expressed in epithelial cells from the isthmus than from the ampulla, whereas PGRMC2 displayed an opposite pattern of expression. However, neither the side relative to the CL nor the pregnancy status changed the gene expression of $\mathrm{P} 4$ receptors.

Western blot analysis of PR detected both PRA and PRB subtypes in oviduct samples, as previously reported
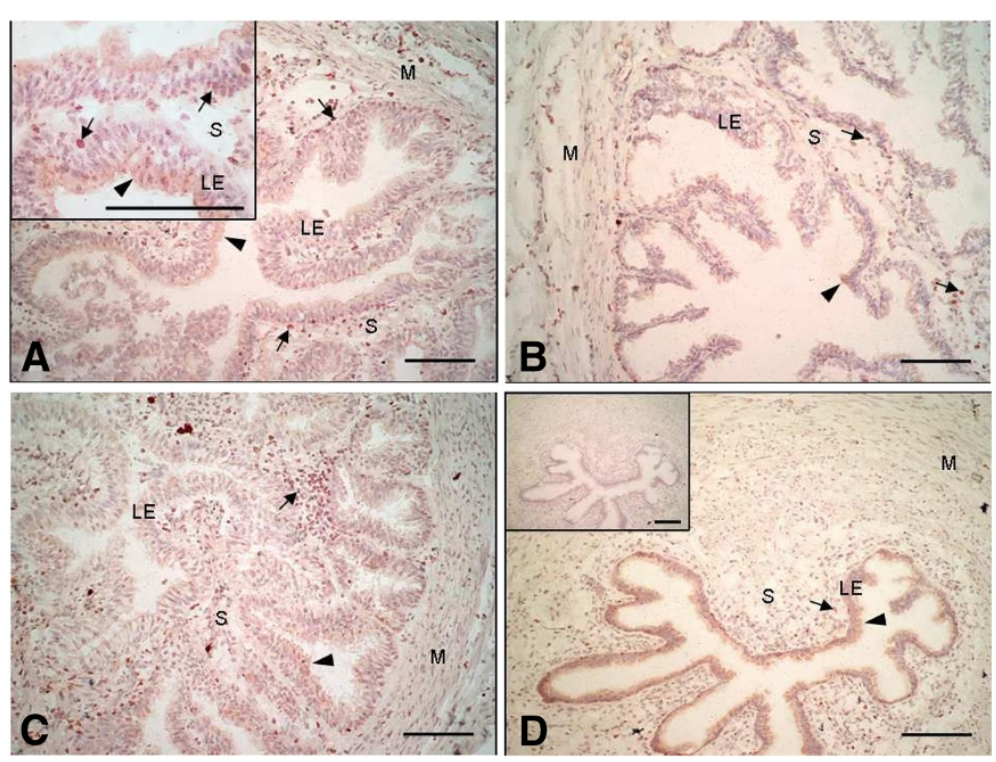

Figure 5 Localisation of PGRMC2 in the bovine oviduct by immunohistochemistry. Representative images of PGRMC2

immunohistochemical localisation in the ampulla $(\mathbf{A}, \mathbf{B})$ and the isthmus $(\mathbf{C}, \mathbf{D})$ of bovine oviducts at Day $1.5(\mathbf{A}, \mathbf{C})$ and Day $5(\mathbf{B}, \mathbf{D})$ post-Al. A inset: magnification of the luminal epithelium showing a nuclear and cytoplasmic staining of epithelial cells. $D$ inset: control section incubated with mouse IgG1 in place of primary antibody. Black arrows indicate nuclear staining and arrow heads indicate cytoplasmic staining. LE: luminal epithelium; S: stroma; M: muscle. Original magnification A-D x200 and A inset x1000. Scale bars: $100 \mu \mathrm{m}$. 

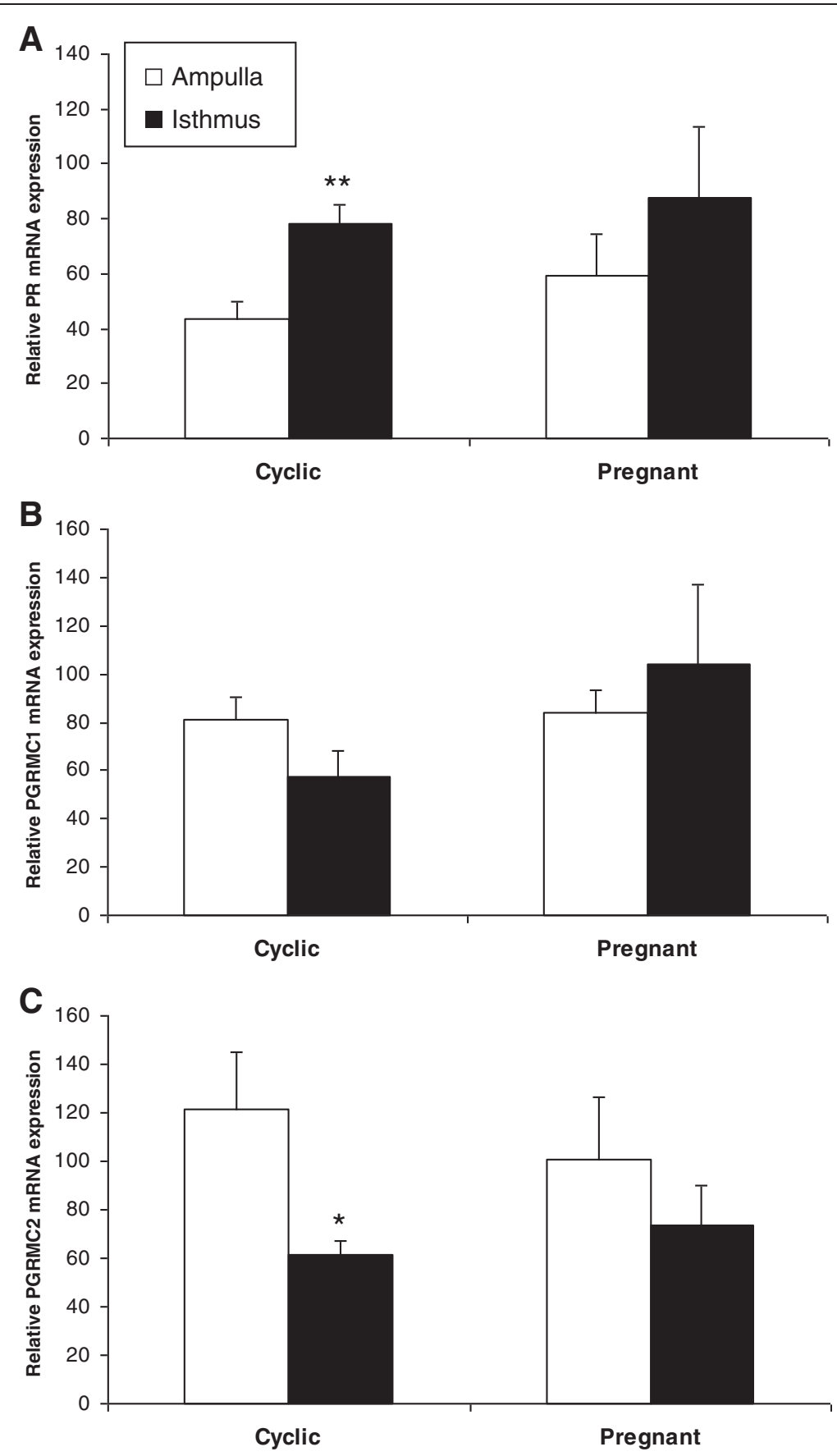

Figure 6 Quantitative expression of PR, PGRMC1 and PGRMC2 mRNAs in the bovine oviduct. Differential mRNA expression of PR (A), PGRMC1 (B) and PGRMC2 (C) between the ampulla and the isthmus in bovine oviduct epithelial cells at Day 3.5 post-ovulation in either cyclic or pregnant cows. Data are means \pm SEM of 4 cows for each status (ipsilateral and contralateral oviducts were grouped). Concentrations of mRNAs were measured in duplicate. Means with designations $\left(^{*}\right)$ and $(* *)$ are significantly different at $p<0.05$ and $p<0.01$, respectively.

in bovine epithelial cells [18]. Although both PRA and PRB bind P4, several studies have shown that, depending on the cell and target genes, PRA and PRB have remarkably different transcriptional activities [31]. However, little information is available so far with respect to the respective roles of PRA and PRB in mediating $\mathrm{P} 4$ action in the mammalian oviduct $[32,33]$. Nevertheless, in the present study, nuclear P4 receptors were expressed between Day 1.5 and Day 5 post-ovulation in both the ampulla and the isthmus. These results are in keeping with earlier reports on PR expression in bovine whole-oviduct sections $[17,34]$ and in isolated oviduct epithelial cells 
[18]. A nuclear immunostaining was observed in the luminal epithelial cell layer, as well as in the muscle layer and stromal tissue, in agreement with earlier reports using the same anti-PR antibody [18] or some others $[17,34,35]$ in bovine oviduct samples collected during the first five days of the oestrous cycle. Accordingly, one of the latter studies reported that the muscle layer was positively stained only during the early luteal phase (days 1-5) compared with other phases of the oestrous cycle in the cow [18].

We observed that PR, PGRMC1 and PGRMC2 were expressed in both the ampulla and isthmus at all stages examined. To our knowledge, this is the first report of PGRMC2 expression in the mammalian oviduct. Western blot analysis for PGRMC2 revealed one band at 26 $\mathrm{kDa}$, as previously described in bovine cumulus and luteal cells [23]. In contrast, two signals at $23 \mathrm{kDa}$ and 28 kDa were observed on PGRMC1 western blots. While the PGRMC1 protein is usually detected as a single signal between 24 and $28 \mathrm{kDa}[21,23,25,26]$, multiple bands were previously reported at the same apparent molecular weights in murine placental tissues [36], which were assumed to represent PGRMC1 oligomers [20]. Various protocols of sample fixation/preparation were used in the latter and present studies and could explain these discrepancies. These conflicting findings could be also attributed to the different tissues/cells and subcellular compartments analysed. Indeed, an antibody from the same source was reported to detect a single band in membrane preparations from human and rat granulosa/ luteal cells $[21,37]$ and multiple bands in whole murine uterine tissues [36].

PGRMC1 has been reported in various subcellular locations, including plasma membrane [21,38], cytosol [36] and nucleus [26,36,37]. In this study, PGRMC1 was mainly localised in the cytosol of luminal epithelial cells, and to a lesser extent in muscular and stromal cells. This differs from findings in a previous study [26] that localised PGRMC1 in the bovine oviduct: the protein was observed in both the nucleus and cytoplasm of the luminal epithelium, endothelium and muscle layer at equivalent staining levels. This divergence may be due to differences in stages of estrous cycle examined, which were not precisely timed in the latter study [26], as well as to differences in antibodies and protocols used. The fact that we had a clear signal in the nucleus for PR and PGRMC2 demonstrates, however, the efficacy of the method used. Furthermore, our results are in keeping with those of Aparicio et al., [23], who localised PGRMC1 only in the cytoplasm of bovine cumulus cells. With the antibody used in the present study, the immunostaining for PGRMC1 was intense in the nucleus of human and rat granulosa/luteal cells [21,37,39]. However, the subcellular localization of PGRMC1 was reported to change dramatically after eCG treatment in the immature rat ovary [21] and depending on the pregnancy stage in the mouse uterus [36]. Thus, the expression of PGRMC1 in various tissues and subcellular compartments of the bovine oviduct might be regulated by the hormonal environment and requires further investigations. The mRNA and/or protein for PGRMC2 have been detected previously in the murine [36] and macaque [40] endometrium, human choriodecidua [41], newborn rat ovary [42], and bovine cumulus cells [23]. Various subcellular localisations for the PGRMC2 protein were previously observed depending on the species and cell tissue: throughout the cytoplasm in bovine cumulus cells [23], in the cytoplasm of the luminal and glandular epithelia and in the nuclei of the stromal cells in the macaque endometrium [40].

Oviducts in the present study were collected from cows treated for estrous synchronisation. Although not well documented, compared with natural cycles, synchronisation protocols may have some impact on the oviduct physiology. Furthermore, oviduct epithelial cells from pregnant animals in the present study were collected from cows inseminated twice at Day 0 and Day 0.5 post-ovulation. Although the lumen of the oviducts was rinsed prior to their use for RNA extraction, sperm cells attached to the luminal epithelium, especially in the isthmic sperm reservoir [43], may have been picked up in these extraction processes. Since PR and also PGRMC1 and PGRMC2 have been identified in porcine [30] and human [22] sperm, one may question whether our results include expression data from bovine sperm cells. Several sets of data seem to exclude this hypothesis. First, the number of spermatozoa counted per entire bovine oviduct between 17 and $20 \mathrm{~h}$ after insemination is around a few tens [44]. Second, nuclei from spermatozoa that transit in the female genital tract are transcriptionally inactive [45] and therefore, mRNAs from spermatozoa have no chance of being co-amplified during the RT-qPCR performed on oviduct samples. Thus, it appears reasonable to exclude possible contamination with bull spermatozoa in our expression data.

While the gene expression of $P R$ in target tissues is classically up-regulated by estradiol and down-regulated by $\mathrm{P} 4$ [31], the factors that regulate the expression of PGRMC1 and PGRMC2 are largely unknown. Nonetheless, $\mathrm{P} 4$ has been identified as a good candidate for the regulation of PGRMC1 gene expression in mouse brain and placenta $[36,38]$ as well as in the endometrium of human [19,46,47] and rhesus monkey [48]. Furthermore, the gene expression of both PGRMC1 and PGRMC2 was recently demonstrated in the canine oviduct, in which their mRNA levels varied significantly with the stage of the estrous cycle [49]. The bovine oviduct ipsilateral to the CL has been shown to contain higher levels of P4 
compared with the contralateral oviduct during the luteal phase of the estrous cycle [50]. However, in this study, quantitative RT-PCR applied on oviduct epithelial cells did not reveal any significant difference in the gene expression of $P R, P G R M C 1$ or PGRMC2 between ipsilateral and contralateral oviducts. Accordingly, Rottmayer et al. [51] reported no difference in $P R$ mRNA expression between epithelial cells collected from bovine ipsilateral and contralateral oviducts. By a transcriptomic approach, 35 genes were found to be differentially expressed between epithelial cells from ipsilateral versus contralateral bovine oviducts collected at Day 3.5 postoestrus [52]. However, in accordance with our findings, genes for P4 receptors were not among the differentially expressed genes. Furthermore, the localisation pattern of the three $\mathrm{P} 4$ receptors observed in this study did not reveal any difference between the two oviducts. In accordance, PGRMC1 was immunolocalised by others in a similar pattern in both oviducts from cyclic cows [26]. In this study, the effect of the pregnancy status on the gene expression of nuclear and membrane $\mathrm{P} 4$ receptors was explored for the first time in the bovine oviduct. Although plasma P4 concentrations do not differ between cyclic and pregnant cows at Day 3.5 post-ovulation [53], local differences in tubal vascularisation and ciliary beating in the bovine oviduct epithelium were previously shown to depend on the presence or absence of an embryo $[8,9]$. However, here, the pregnancy status did not influence the expression of any of the P4 receptors at Day 3.5 post-ovulation. Similarly, in the bovine endometrium, the level of PR mRNAs was not influenced by the pregnancy status during the early post-ovulation period (Days 5-7) [54]. Our results do not exclude differential expression of these receptors between cyclic and pregnant cows in other oviductal tissue layers or at later stages post-ovulation. Indeed, in the bovine endometrium, $P R$ mRNA concentration was lower in pregnant cows than in cyclic cows at Day 13 post-ovulation, but not earlier [54].

In the present study, the $P R$ gene was more highly expressed in epithelial cells from the isthmus than from the ampulla, whereas PGRMC2 displayed an opposite pattern of expression. Higher amounts of $P R$ mRNAs in the isthmus compared with the ampulla were previously reported in the bovine $[18,34]$ and rat [32] oviduct luminal epithelia. However, in the pig oviduct, $P R$ mRNAs were measured at comparable levels in both oviduct regions [55]. As the ampulla is mainly implicated in oocyte transport and fertilisation [7], a positive effect of PGRMC2 in these tubal events might be assumed. Furthermore, a higher expression of PR in the isthmus might have beneficial effects in the specific functions of this part of the oviduct, i.e. in the storage of spermatozoa before fertilisation and/or in the timed transport of the embryo toward the utero-tubal junction [7]. The factors that could regulate the differential gene expression of $P R$ and PGRMC2 in the two parts of the bovine oviduct are still unknown. Previous measurement of P4 levels in whole-oviduct sections collected during the first 5 days post-ovulation revealed no difference in $\mathrm{P} 4$ concentrations between the ampulla and isthmus [50]. Thus, it seems likely that factors other than local P4 regulate the region-specific gene expression of $P R$ and $P G R M C 2$ in the oviduct epithelium.

An important question remains the potential roles of nuclear and membrane P4 receptors in the regulation of tubal functions. A role for PGRMC1 in the mediation of the anti-apoptotic effects of $\mathrm{P} 4$ has been reported in ovarian granulosa cells $[19-21,56]$. Furthermore, PGRMC1 has been recently implicated in the mediation of myometrium relaxation during pregnancy in human [25]. Of interest, a proteomic approach showed that PGRMC2 was upregulated in the human choriodecidua during term and preterm labor [41]. A central role of the oviduct during the post-ovulation period is to allow the transport of the cumulus-oocyte complex to the site of fertilisation, then of the early embryo toward the uterus, achieved by synchronised ciliary beating, smooth muscle contraction and flow of tubal secretions [14]. It might be assumed that both PGRMC1 and PGRMC2 are involved in tubal contraction and relaxation. However, as both receptors were expressed in the luminal epithelium, the mediation of $\mathrm{P} 4$ action on tubal ciliary beating or fluid secretion cannot be excluded. Further experiments would be required to determine the potential functions of $\mathrm{P} 4$ nuclear and membrane receptors in the bovine oviduct.

\section{Conclusions}

The present study confirms the expression of PR and PGRMC1 and demonstrates for the first time the expression of PGRMC2 in several compartments of the bovine oviduct. Furthermore, the expression of $P R$ and PGRMC2 mRNAs in oviduct epithelial cells at Day 3.5 postovulation varied with the oviduct region. These results suggest that $\mathrm{P} 4$ regulates the tubal micro-environment in the early post-ovulation period in the cow and mediates its actions through classical as well as non classical pathways.

\section{Abbreviations}

Al: Artificial insemination; CL: Corpus luteum; mRNA: Messenger ribonucleic acid; P4: Progesterone; PGRMC: Progesterone receptor membrane component; PR: Progesterone receptor; qPCR: Quantitative real-time polymerase chain reaction; RT-PCR: Reverse transcript-polymerase chain reaction.

\section{Competing interests}

The authors declare that they have no competing interests. 


\section{Authors' contributions}

MSD designed and conducted experiment, analysed data and drafted the paper; OS designed and conducted experiment, analysed data and revised the manuscript; SP conducted experiment and analysed data; MC conducted experiment and analysed data; FC designed and conducted experiment, analysed data and revised the manuscript. All authors read and approved the final manuscript.

\section{Acknowledgments}

The authors express their gratitude to Dr. Marc Chodkiewicz for the critical review of the manuscript. The authors are grateful to Christophe Richard for taking good care of the animals, to the staff of the INRA slaughterhouses in Nouzilly and Theix for their technical assistance, to Corinne Giraud-Delville, Aurélie Chaulot-Talmon and Fabienne Nuttinck for their help in tissue collection and RNA extraction. The authors wish to thank Pr. Martin Wehling, from the University of Heidelberg, for providing the anti-PGRMC1 antibody. This work was supported by the Institut National de la Recherche Agronomique and the French Ministry of Agriculture and Fisheries.

\section{Author details}

'INRA, UMR 1198 Biologie du Développement et Reproduction, F-78352, Jouy-en-Josas, France. ${ }^{2}$ Université Paris-Est, Ecole Nationale Vétérinaire d'Alfort, UMR 1198, 7 av. du Général-de-Gaulle, F-94704, Maisons-Alfort, France. ${ }^{3}$ AgroParisTech, UFR Génétique Elevage Reproduction, 16 rue Claude Bernard, F-75231, Paris CEDEX 05, France.

Received: 16 May 2012 Accepted: 3 August 2012

Published: 7 September 2012

\section{References}

1. Robinson RS, Hammond AJ, Wathes DC, Hunter MG, Mann GE: Corpus luteum-endometrium-embryo interactions in the dairy cow: underlying mechanisms and clinical relevance. Reprod Domest Anim 2008, 43(Suppl 2):104-112.

2. Demetrio DG, Santos RM, Demetrio CG, Vasconcelos JL: Factors affecting conception rates following artificial insemination or embryo transfer in lactating Holstein cows. J Dairy Sci 2007, 90:5073-5082.

3. Green MP, Hunter MG, Mann GE: Relationships between maternal hormone secretion and embryo development on day 5 of pregnancy in dairy cows. Anim Reprod Sci 2005, 88:179-189.

4. Mann GE, Fray MD, Lamming GE: Effects of time of progesterone supplementation on embryo development and interferon-tau production in the cow. Vet J 2006, 171:500-503.

5. McNeill RE, Diskin MG, Sreenan JM, Morris DG: Associations between milk progesterone concentration on different days and with embryo survival during the early luteal phase in dairy cows. Theriogenology 2006, 65:1435-1441.

6. Stronge AJ, Sreenan JM, Diskin MG, Mee JF, Kenny DA, Morris DG: Postinsemination milk progesterone concentration and embryo survival in dairy cows. Theriogenology 2005, 64:1212-1224.

7. Hunter RH: Components of oviduct physiology in eutherian mammals. Biol Rev Camb Philos Soc 2012, 287:244-255.

8. Kolle S, Dubielzig S, Reese S, Wehrend A, Konig P, Kummer W: Ciliary transport, gamete interaction, and effects of the early embryo in the oviduct: ex vivo analyses using a new digital videomicroscopic system in the cow. Biol Reprod 2009, 81:267-274.

9. Kolle S, Reese S, Kummer W: New aspects of gamete transport fertilization, and embryonic development in the oviduct gained by means of live cell imaging. Theriogenology 2010, 73:786-795.

10. Aguilar J, Reyley M: The uterine tubal fluids: secretion, composition and biological effects. Anim Reprod 2005, 2:91-105.

11. Leese HJ, Tay Jl, Reischl J, Downing SJ: Formation of Fallopian tubal fluid: role of a neglected epithelium. Reproduction 2001, 121:339-346.

12. Gerena RL, Killian GJ: Electrophoretic characterization of proteins in oviduct fluid of cows during the estrous cycle. J Exp Zool 1990, 256:113-120.

13. Hugentobler SA, Sreenan JM, Humpherson PG, Leese HJ, Diskin MG, Morris DG: Effects of changes in the concentration of systemic progesterone on ions, amino acids and energy substrates in cattle oviduct and uterine fluid and blood. Reprod Fertil Dev 2010, 22:684-694.

14. Croxatto HB: Physiology of gamete and embryo transport through the fallopian tube. Reprod Biomed Online 2002, 4:160-169.
15. Bennett WA, Watts TL, Blair WD, Waldhalm SJ, Fuquay JW: Patterns of oviducal motility in the cow during the oestrous cycle. J Reprod Fertil 1988, 83:537-543.

16. Wessel T, Schuchter U, Walt H: Ciliary motility in bovine oviducts for sensing rapid non-genomic reactions upon exposure to progesterone. Horm Metab Res 2004, 36:136-141.

17. Saruhan BG, Sagsoz H, Akbalik ME, Ketani MA: Distribution of estrogen receptor alpha and progesterone receptor $B$ in the bovine oviduct during the follicular and luteal phases of the sexual cycle: an immunohistochemical and semi-quantitative study. Biotech Histochem 2010, 86:315-325

18. Ulbrich SE, Kettler A, Einspanier R: Expression and localization of estrogen receptor alpha, estrogen receptor beta and progesterone receptor in the bovine oviduct in vivo and in vitro. J Steroid Biochem Mol Biol 2003, 84:279-289.

19. Gellersen B, Fernandes MS, Brosens JJ: Non-genomic progesterone actions in female reproduction. Hum Reprod Update 2009, 15:119-138.

20. Cahill MA: Progesterone receptor membrane component 1: an integrative review. J Steroid Biochem Mol Biol 2007, 105:16-36.

21. Peluso JJ, Pappalardo A, Losel R, Wehling M: Progesterone membrane receptor component 1 expression in the immature rat ovary and its role in mediating progesterone's antiapoptotic action. Endocrinology 2006, 147:3133-3140.

22. Losel R, Breiter S, Seyfert M, Wehling M, Falkenstein E: Classic and nonclassic progesterone receptors are both expressed in human spermatozoa. Horm Metab Res 2005, 37:10-14.

23. Aparicio IM, Garcia-Herreros M, O'Shea LC, Hensey C, Lonergan P, Fair T: Expression, regulation, and function of progesterone receptors in bovine cumulus oocyte complexes during in vitro maturation. Biol Reprod 2011 84:910-921.

24. Luciano AM, Lodde V, Franciosi F, Ceciliani F, Peluso JJ: Progesterone receptor membrane component 1 expression and putative function in bovine oocyte maturation, fertilization, and early embryonic development. Reproduction 2010, 140:663-672.

25. Wu W, Shi SQ, Huang HJ, Balducci J, Garfield RE: Changes in PGRMC1, a potential progesterone receptor, in human myometrium during pregnancy and labour at term and preterm. Mol Hum Reprod 2011, 17:233-242.

26. Luciano AM, Corbani D, Lodde V, Tessaro I, Franciosi F, Peluso JJ, Modina S: Expression of progesterone receptor membrane component-1 in bovine reproductive system during estrous cycle. Eur J Histochem 2011, 55:e27.

27. Ireland JJ, Murphee RL, Coulson PB: Accuracy of predicting stages of bovine estrous cycle by gross appearance of the corpus luteum. J Dairy sci 1980, 63:155-160.

28. Primer3 [http://frodo.wi.mit.edu/primer3/].

29. BLAST [http://blast.ncbi.nlm.nih.gov/Blast.cgi].

30. Losel R, Dorn-Beineke A, Falkenstein E, Wehling M, Feuring M: Porcine spermatozoa contain more than one membrane progesterone receptor. Int J Biochem Cell Biol 2004, 36:1532-1541.

31. Graham JD, Clarke CL: Physiological action of progesterone in target tissues. Endocr Rev 1997, 18:502-519.

32. Okada A, Ohta $Y$, Inoue S, Hiroi H, Muramatsu M, Iquchi T: Expression of estrogen, progesterone and androgen receptors in the oviduct of developing, cycling and pre-implantation rats. J Mol Endocrinol 2003, 30:301-315

33. Peiro R, Herrler A, Santacreu MA, Merchan M, Argente MJ, Garcia ML, Folch $J M$, Blasco A: Expression of progesterone receptor related to the polymorphism in the PGR gene in the rabbit reproductive tract. J Anim Sci 2010, 88:421-427.

34. Valle GR, Cassali GD, Nogueira JC, Castro AC, Reis AM, Cardoso FM, Figueiredo CB, Nascimento EF: Nuclear estrogen and progesterone receptors in the oviduct of heifers under natural and superovulated estrous cycles. Anim Reprod Sci 2007, 101:28-37.

35. Kenngott RA, Vermehren M, Sauer U, Ebach K, Sinowatz F: Cellular expression and localization of estrogen receptor alpha and progesterone receptor $\mathrm{mRNA}$ in the bovine oviduct combining laser-assisted microdissection, quantitative PCR, and in situ hybridization. $J$ Histochem Cytochem 2011, 59:312-327.

36. Zhang L, Kanda Y, Roberts DJ, Ecker JL, Losel R, Wehling M, Peluso JJ, Pru JK: Expression of progesterone receptor membrane component 1 and its 
partner serpine 1 mRNA binding protein in uterine and placental tissues of the mouse and human. Mol Cell Endocrinol 2008, 287:81-89.

37. Engmann L, Losel R, Wehling M, Peluso JJ: Progesterone regulation of human granulosa/luteal cell viability by an RU486-independent mechanism. J Clin Endocrinol Metab 2006, 91:4962-4968.

38. Krebs CJ, Jarvis ED, Chan J, Lydon JP, Ogawa S, Pfaff DW: A membraneassociated progesterone-binding protein, $25-\mathrm{Dx}$, is regulated by progesterone in brain regions involved in female reproductive behaviors. Proc Natl Acad Sci USA 2000, 97:12816-12821.

39. Peluso JJ, Romak J, Liu X: Progesterone receptor membrane component-1 (PGRMC1) is the mediator of progesterone's antiapoptotic action in spontaneously immortalized granulosa cells as revealed by PGRMC small interfering ribonucleic acid treatment and functional analysis of PGRMC1 mutations. Endocrinology 2008, 149:534-543.

40. Keator CS, Mah K, Slayden OD: Alterations in progesterone receptor membrane component 2 (PGRMC2) in the endometrium of macaques afflicted with advanced endometriosis. Mol Hum Reprod 2012, 27:1723-1734

41. Shankar R, Johnson MP, Williamson NA, Cullinane F, Purcell AW, Moses EK, Brennecke SP: Molecular markers of preterm labor in the choriodecidua. Reprod Sci 2010, 17:297-310.

42. Nilsson EE, Stanfield J, Skinner MK: Interactions between progesterone and tumor necrosis factor-alpha in the regulation of primordial follicle assembly. Reproduction 2006, 132:877-886.

43. Lefebvre R, Chenoweth PJ, Drost M, LeClear CT, MacCubbin M, Dutton JT, Suarez SS: Characterization of the oviductal sperm reservoir in cattle. Biol Reprod 1995, 53:1066-1074.

44. Sostaric E, Dieleman SJ, van de Lest CH, Colenbrander B, Vos PL, Garcia-Gil N, Gadella BM: Sperm binding properties and secretory activity of the bovine oviduct immediately before and after ovulation. Mol Reprod Dev 2008, 75:60-74.

45. Steger K: Transcriptional and translational regulation of gene expression in haploid spermatids. Anat Embryol (Berl) 1999, 199:471-487.

46. Kao LC, Tulac S, Lobo S, Imani B, Yang JP, Germeyer A, Osteen K, Taylor RN, Lessey BA, Giudice LC: Global gene profiling in human endometrium during the window of implantation. Endocrinology 2002, 143:2119-2138.

47. Talbi S, Hamilton AE, Vo KC, Tulac S, Overgaard MT, Dosiou C, Le Shay N, Nezhat CN, Kempson R, Lessey BA, et al: Molecular phenotyping of human endometrium distinguishes menstrual cycle phases and underlying biological processes in normo-ovulatory women. Endocrinology 2006, 147:1097-1121.

48. Ace Cl, Okulicz WC: Microarray profiling of progesterone-regulated endometrial genes during the rhesus monkey secretory phase. Reprod Biol Endocrinol 2004, 2:54.

49. Tahir MZ, Reynaud K, Thoumire S, Chastant-Maillard S, Saint-Dizier M: Expression of nuclear and membrane progesterone receptors in the canine oviduct during the periovulatory period. Reprod Fertil Dev 2011 24:147. abstract 170 .

50. Wijayagunawardane MPB, Miyamoto A, Cerbito WA, Acosta TJ, Takagi M, Sato K: Local distributions of oviductal estradiol, progesterone, prostaglandins, oxytocin and endothelin-1 in the cyclic cow. Theriogenology 1998, 49:607-618.

51. Rottmayer R, Ulbrich SE, Kolle S, Prelle K, Neumueller C, Sinowatz F, Meyer $H H$, Wolf E, Hiendleder S: A bovine oviduct epithelial cell suspension culture system suitable for studying embryo-maternal interactions: morphological and functional characterization. Reproduction 2006, 132:637-648.

52. Bauersachs S, Blum H, Mallok S, Wenigerkind H, Rief S, Prelle K, Wolf E: Regulation of ipsilateral and contralateral bovine oviduct epithelial cell function in the postovulation period: a transcriptomics approach. Biol Reprod 2003, 68:1170-1177.

53. Carter F, Forde N, Duffy P, Wade M, Fair T, Crowe MA, Evans AC, Kenny DA Roche JF, Lonergan P: Effect of increasing progesterone concentration from Day 3 of pregnancy on subsequent embryo survival and development in beef heifers. Reprod Fertil Dev 2008, 20:368-375.

54. Okumu LA, Forde N, Fahey AG, Fitzpatrick E, Roche JF, Crowe MA, Lonergan $P$ : The effect of elevated progesterone and pregnancy status on mRNA expression and localisation of progesterone and oestrogen receptors in the bovine uterus. Reproduction 2010, 140:143-153.

55. Peralta LE, Olarte MR, Arganaraz M, Ciocca D, Miceli DC: Progesterone receptors: their localization, binding activity and expression in the pig oviduct during follicular and luteal phases. Domest Anim Endocrinol 2005, 28:74-84.

56. Thomas $\mathrm{P}$ : Characteristics of membrane progestin receptor alpha (mPRalpha) and progesterone membrane receptor component 1 (PGMRC1) and their roles in mediating rapid progestin actions. Front Neuroendocrinol 2008, 29:292-312.

doi:10.1186/1477-7827-10-76

Cite this article as: Saint-Dizier et al:: Expression of nuclear progesterone receptor and progesterone receptor membrane components 1 and 2 in the oviduct of cyclic and pregnant cows during the post-ovulation period. Reproductive Biology and Endocrinology 2012 10:76.

\section{Submit your next manuscript to BioMed Central and take full advantage of:}

- Convenient online submission

- Thorough peer review

- No space constraints or color figure charges

- Immediate publication on acceptance

- Inclusion in PubMed, CAS, Scopus and Google Scholar

- Research which is freely available for redistribution
() Biomed Central 